\title{
The Incidence of Soot and Surface Boundary Layer Meteorology in Port Harcourt Metropolis, Nigeria
}

\author{
Vincent Ezikornwor Weli ${ }^{1 *}$, Jimmy Adegoke² and Bassey Justine Eyo ${ }^{3}$ \\ ${ }^{1}$ Department of Geography and Environmental Management, University of Port Harcourt, Nigeria \\ ${ }^{2}$ Director, Center for Applied Environmental Research (CAER), University of Missouri-Kansas City, USA \\ ${ }^{3}$ Center for Disaster Risk and Development Studies, University of Port Harcourt, Nigeria
}

\begin{abstract}
Atmospheric Black Carbon effects the hygroscopicity of cloud condensation nuclei, which in turn, effects atmospheric heating, stability, large scale circulation and overall cloud albedo. The study investigated the concentration level of soot and the surface boundary meteorology in Port Harcourt city. Sampling was done from five major different land use typologies with the aid of aeroset SPM 531, portable multi-gas monitor (Aeroqual 300 series) and Extech model 45160 . Findings showed that the level of concentration of black carbon at different land use areas of Port Harcourt City was relatively very high with minimum mean value of $2.33 \pm 1.66 \mu \mathrm{g} / \mathrm{m}^{3}$ and maximum mean value of $4.66 \pm 5.43\left(\mu \mathrm{g} / \mathrm{m}^{3}\right)$ in the morning hours. For the evening period, the minimum mean of $1.25 \pm 0.62\left(\mu \mathrm{g} / \mathrm{M}^{3}\right)$ and maximum mean of $4.75 \pm 3.13\left(\mu \mathrm{g} / \mathrm{M}^{3}\right)$ For the morning study period, there was no significant difference in the level of concentration of soot at the respective land use areas, since p-values were $(0.33$ and 0.06$)$; and there was significant difference in the air pollutant parameters $\left(\mathrm{NO}_{2}\right.$ and $\left.\mathrm{CO}\right)$ across the different land use areas, since $\mathrm{p}$-values were $(0.00$ and 0.00$)$. The meteorological predictors revealed that humidity (Beta $=-0.002, p<5 \%$ ), temperature (Beta $=-0.001, p>5 \%)$ and wind speed (Beta $=0.006, p<5 \%$ ) are significant predictors of overall detection $\mathrm{NO}_{2}$ for the morning period. While for the evening study period, the individual predictors were insignificant to the overall detection $\mathrm{NO}_{2}$, since humidity (Beta $=-0.003, p>5 \%$ ), temperature (Beta $=-0.042, p>5 \%$ ) and wind speed (Beta $=0.006, p>5 \%$ ). Enactment and implementation of laws against air pollution is strongly advocated.
\end{abstract}

Keywords: Black carbon; Surface boundary layer; Meteorology; Troposphere; Port Harcourt

\section{Introduction}

The recent incidence of Soot over the lower troposphere of Port Harcourt and other parts of the world has attracted the attention of environmental experts, air pollution meteorologist and climatologist [1-6]. The Intergovernmental Panel on Climate Change [7] has estimated that the global mean clear-sky radiative forcing of $\mathrm{BC}$ is $0.23( \pm 0.25) \mathrm{W} \mathrm{m}^{-2}$, which is approximately half the value of methane, the second most important greenhouse gas after carbon dioxide [8]. Atmospheric carbonaceous aerosols constitute a significant part of the atmospheric aerosols, while a large part of them consists of an organic material ( $50 \%)$ [9].The carbonaceous atmospheric particulate matter consists of black carbon (otherwise called elemental carbon (EC) and a variety of organic compounds.

Recent concerns and findings showed that the current illegal artisanal mining of crude oil along pipelines crisscrossing the coastal areas of Rivers state is the reason for the incidence of soot in the lower troposphere of the city of Port Harcourt. Aerosol black carbon (BC), produced mainly due to incomplete combustion of fossil fuel or biomass, is amongst the strongest contributors to the radiative warming of the atmosphere [10], through its strong absorption over a wide wavelength range (from UV to IR). They can heat the air, alter atmosphere stability, large-scale circulations and cloud albedo by changing the hygroscopicity of cloud condensation nuclei with the total forcing of $1.1 \mathrm{~W} / \mathrm{m}^{2}$ [11]. $\mathrm{BC}$ aerosols are inert in nature as a result of predominant sub-micron size and chemical structure. Being in the fine size range (median diameters in the range 100-200 nm), they bear a long atmospheric residence time, thereby leading to deterioration of air quality and health hazards as easily respirable [9]. In addition, $\mathrm{BC}$-containing particles are also associated with adverse effects such as crop yields decrease, contaminating building materials and adversely impact terrestrial and aquatic ecosystems [12-14]. Since the incidence of this new pollution episode in the city, the impacts of $\mathrm{BC}$ have been enormous among the residents. Therefore, a concerted effort is needed to combat this danger.

In the city of Port Harcourt several studies exist on air pollution, they include [15] study which revealed that most people usually found around traffic jam-packed junctions especially in Port Harcourt are inhaling the lethal gas (carbon monoxide) since the concentration of the gas vary between $36.07 \pm 2.6 \mathrm{ppm}$ and $14.3 \pm 0.7 \mathrm{ppm}$. [16] Revealed that there was the significant concentration of pollutants during the dry season for both urban and rural areas closely followed by that of the transitional period then the wet season. There were significant variances in the mean concentrations of PM 10, TSP, $\mathrm{NO}_{2}, \mathrm{CO}$ and $\mathrm{CH}_{4}$ during the wet, transition and dry seasons respectively at 0.05 significant level between the urban and rural zones. Others include [17-22]. Similarly, Weli and Adegoke [23] using Satellite platform determined Particulate Load over Port Harcourt during Soot Incidents. A critical look at various literatures reveal that much work has been done on the incidence of soot with real-time data obtained at ground level at different locations in the city of Port Harcourt and particularly the influence of the interplay between surface boundary layer meteorology and land use on the concentration and dispersion of soot concentration

${ }^{*}$ Corresponding author: Vincent Ezikornwor Weli, Department of Geography and Environmental Management, University of Port Harcourt, Nigeria, Tel: +234-0806-8938318; E-mail: welivinezi@yahoo.com

Received April 28, 2018; Accepted June 26, 2018; Published June 30, 2018

Citation: Weli VE, Adegoke J, Eyo BJ (2018) The Incidence of Soot and Surface Boundary Layer Meteorology in Port Harcourt Metropolis, Nigeria. J Climatol Weather Forecasting 6: 233. doi:10.4172/2332-2594.1000233

Copyright: $\odot 2018$ Weli VE, et al. This is an open-access article distributed under the terms of the Creative Commons Attribution License, which permits unrestricted use, distribution, and reproduction in any medium, provided the original author and source are credited. 
Citation: Weli VE, Adegoke J, Eyo BJ (2018) The Incidence of Soot and Surface Boundary Layer Meteorology in Port Harcourt Metropolis, Nigeria. J Climatol Weather Forecasting 6: 233. doi:10.4172/2332-2594.1000233

Page 2 of 9

in the lower troposphere of Port Harcourt city remains a gap which this paper intends to fill.

\section{Study Area}

Port Harcourt is the capital of Rivers State. It is the main city in the state and has one of the largest seaports in the Niger Delta region of Nigeria. It is the hub of industrial, commercial, administration and other activities in the state. The city lies on latitude 00 231-70 $301 \mathrm{E}$ and 50 451-400 $151 \mathrm{~N}$ (Figure 1). It covers an estimated area of 1811.6 square kilometers. The city is bounded in the north by Imo and Abia States east by Akwa-Ibom State, West by Bayelsa State and south by the Atlantic Ocean. Weather systems particularly rainfall in a city is primarily a result of the interplay between two major pressure and wind systems. These are the two dynamically generated sub-tropical highpressure cells centered over Azores Archipelago (off the west coast of North Africa) and St. Hellena Islands (off the coast of Namibia). These high-pressure centers (or anticyclones) which are permanent generate and drive respectively the North-East trade winds and the South-West winds, which are the northward extension of the re-curved South-East trade winds of the South Atlantic Ocean. The major rainfall controls over the region are, apart from the seasonal location of the ITD, the distance inland from the coast and relief. Generally, rainfall over Nigeria diminishes with increasing distance from the moisture source in the South Atlantic. Thus, coastal areas like the Port Harcourt region, receive heavier and more persistent rainfall because the South-West wind is strong. The strength of the air mass is reduced as it penetrates inland. This also affects temperature. The ascent of air over high ground produces cooling which can lead to condensation and precipitation. Pollution in the atmospheric medium travels the farthest and industrial emissions are one of the most important sources of air pollution. The implications of the location pattern of industries for pollution are many. The dominant air mass over Port Harcourt is the South West Trade Wind. Detailed wind flow characteristics over the city include periodic doses of emission from the major industrial locations around the city. The incidence of land breeze, as well as, the Harmattan factor transfers emissions into the city [24].

\section{Conceptual framework and methodology}

The conceptual framework upon which this study is rooted in the concept of Disaster Risk Reduction (DRR). Disaster Risk Reduction is the methodological development and application of guiding principles, approaches and practices to reduce the level susceptibility and catastrophic threats via out the society to prevent and or mitigate the undesirable effect of vulnerability within the wider perspective of sustainable development. According to the United Nations, Office on Disaster Risk reduction [25], disaster risk reduction (DRR) is the theory and practice of plummeting disaster risks through logical efforts to analyze and lessen the underlying factors of disasters. Minimizing exposure to hazards, reduction in the vulnerability of people and property, efficient use of land/management of the environs/ surroundings and effective preparedness and early warning plans/ actions for adverse events are illustrations of disaster risk reduction. This concept is significant to this study because it aims at reducing Disaster risk through ensuring the right human practical approach to reducing the vulnerability of a population/community/environment to the potentials of soot-induced disaster, as well as enhancing the preparedness level and early warning for an elevated concentration of black carbon as in this case.

The sample frame consists of five (5) respective land use areas (viz; Industrial, high-density residential, low-density residential,
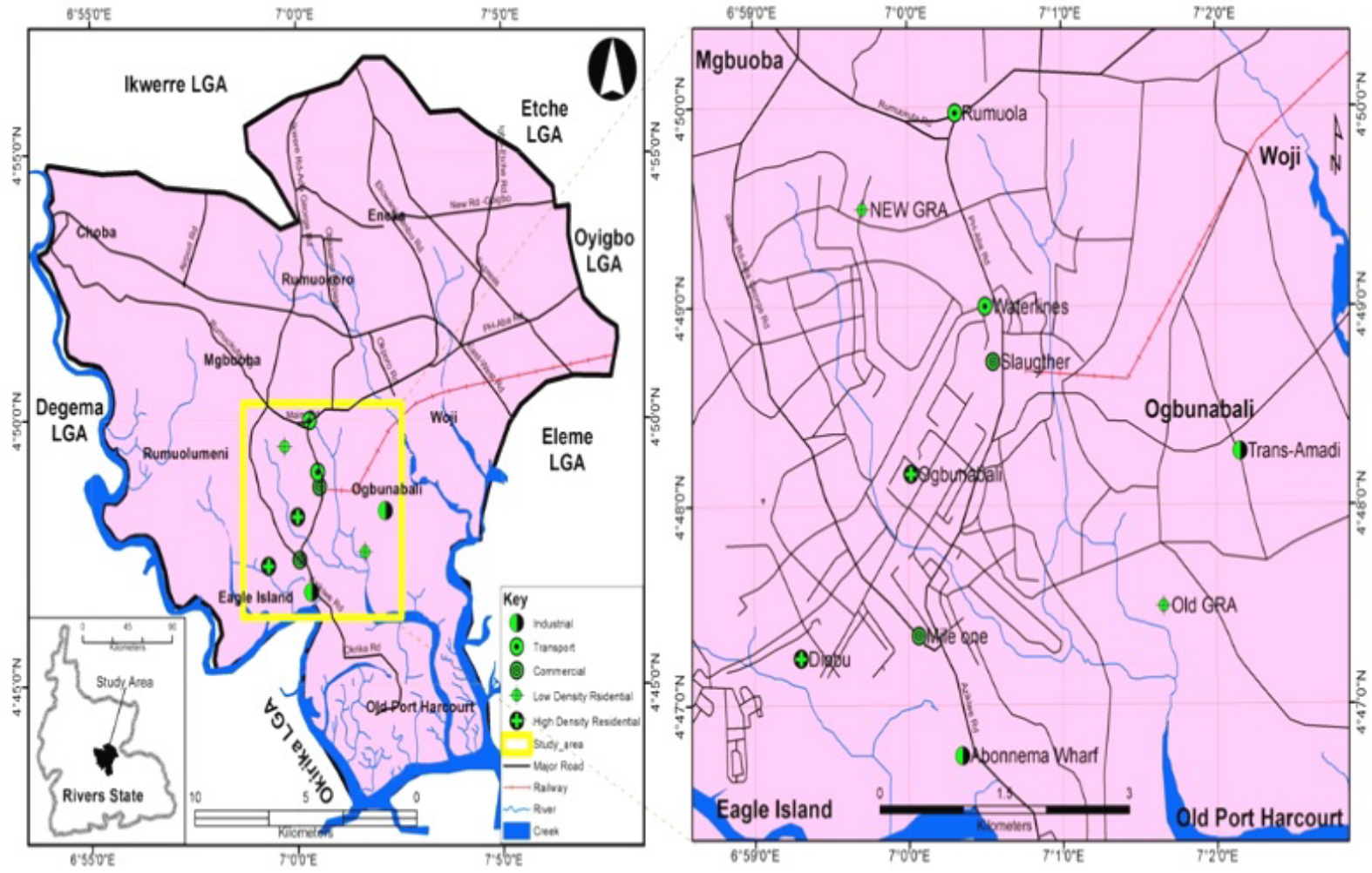

Figure 1: Port Harcourt Metropolis showing sample points. 
commercial and transport) (Figure 2) in Port Harcourt city. Two (2) sampling points were selected by convenience sampling from each of the respective land use areas. The pollutants measured were Particulate Matter $\mathrm{PM}_{1}, \mathrm{PM}_{25}, \mathrm{CO}, \mathrm{SO}_{2}$, and $\mathrm{NO}_{2}$. The different land use map of the city was acquired with Landsat Imagery of $30 \mathrm{~m} \mathrm{X} 30 \mathrm{~m}$ resolution, and was gridded $500 \mathrm{~m} \mathrm{X} \mathrm{500m} \mathrm{and} \mathrm{coded} \mathrm{to} \mathrm{represent} \mathrm{each} \mathrm{land} \mathrm{use,} \mathrm{from}$ where selections were made to represent each land use. Accordingly, the $\mathrm{x}$ (latitude) and $\mathrm{y}$ (longitude) coordinates of air quality sampling locations were obtained via the help of Global Positioning System (GPS) tool. This aided in the mapping of sample locations of varying concentrations levels.

An aerostat SPM 531 particle mass monitor was calibrated and used for the measurement of particulate matter size of PM1 and 2.5 which falls into the soot categories. The instrument continuously samples air at $2.83 \mathrm{~L} \mathrm{~min}-1$. The average number of particles counted $\left(\mathrm{L} \mathrm{min}^{-1}\right)$ in each channel was recorded by the data acquisition system. Air leaks or debris in the particle sensor which may result in false counts when sampling was taken into consideration. Zero count test was performed hourly to ensure proper operation of the particulate counter using zero count filter (PNG3111). The measurement was done by holding the sensor at 1.5-meter-high above the ground level in the direction of the prevailing wind and measurement taken at stability. The wind speed, ambient temperature, and relative humidity were measured using Extech model 45160 handheld weather station. Criteria pollutant $\mathrm{NO} 2, \mathrm{SO} 2$, and $\mathrm{CO}$ were measured using portable multi-gas monitor (Aeroqual 300 series). The measurement was done by holding the sensor to about 1.5 meters above the ground for 3 minutes and recorded at stability (Table 1 ). The averages were used for inferences and computations.

The Analysis of Variance (ANOVA) and Multiple Linear Regression (MLR) analysis were done to unravel the variation in soot concentration and to understand the relationship between meteorological parameters and Black carbon (soot) concentration at the sample points respectively.

The multiple regression technique is in the form;

$$
\mathrm{Y}=\mathrm{a}+\beta 1 \times 1+\beta 2 \times 2+\beta 3 \times 3 . .+\beta \mathrm{iji}+\mathrm{e}
$$

Where,

$$
\begin{aligned}
& \mathrm{Y}=\text { Pollutant concentration, } \\
& \mathrm{a}=\text { Constant term }
\end{aligned}
$$

\section{$\beta 1 \beta 2 \beta 3 \ldots \beta J=$ Regression coefficients}

$\mathrm{X} 1 \mathrm{X} 2 \mathrm{X} 3$...XJ = Independent variables (air temperature, wind speed and relative humidity)

\section{Results and Discussion}

\section{Mean and standard deviation of pollutants at different landuse}

Using multiple comparisons (Least Significant Difference), findings showed that $\mathrm{PM}_{1}$, humidity, and temperature were the same for land use types (Table 2). Again, $\mathrm{PM}_{2.5}$ is significantly the same for low residential and transport land use type but significantly different from commercial land use type. Commercial land use is significantly different from low residential and transport land use but not significantly different from high residential and industrial land use types. The table further shows that industrial, high residential, low residential and commercial land uses are not significantly different for

\begin{tabular}{|c|c|c|c|c|c|}
\hline $\mathbf{S} / \mathbf{N}$ & $\begin{array}{l}\text { Land Use } \\
\text { Type }\end{array}$ & $\begin{array}{l}\text { Station } \\
\text { locations }\end{array}$ & Points & GPS Latitude & $\begin{array}{l}\text { Location } \\
\text { Longitude }\end{array}$ \\
\hline \multirow{2}{*}{1} & \multirow{2}{*}{ Industrial } & Trans-Amadi & TA & N 04' 48.268 & E $0077^{\prime} 02.148$ \\
\hline & & Abonnema Wharf & AW & N 04'46.745 & E 007'00.340 \\
\hline \multirow{2}{*}{2} & \multirow{2}{*}{$\begin{array}{l}\text { High density } \\
\text { residential }\end{array}$} & Ogbunuabali & OG & N 04' 48.158 & E 007'00.009 \\
\hline & & Diobu & DB & N 04' 47.234 & E 006' 69.891 \\
\hline \multirow{2}{*}{3} & \multirow{2}{*}{$\begin{array}{l}\text { Low density } \\
\text { residential }\end{array}$} & Old GRA & OG & N 04' 47.494 & E 007'01.647 \\
\hline & & New GRA & NG & N 04' 4929.26 & E 006' 5941.92 \\
\hline \multirow{2}{*}{4} & \multirow{2}{*}{ Commercial } & Mile One & $\mathrm{MO}$ & N $044^{\prime} 47.347$ & E 007'00.058 \\
\hline & & Slaughter & SL & N 04' 4843.31 & E 007' 2042.69 \\
\hline \multirow{2}{*}{5} & \multirow{2}{*}{ Transport } & Waterlines & WL & N 04' 48.999 & E 007 ' 00.495 \\
\hline & & Rumuola & $\mathrm{RL}$ & N 04' 49.970 & E 007'00.303 \\
\hline
\end{tabular}

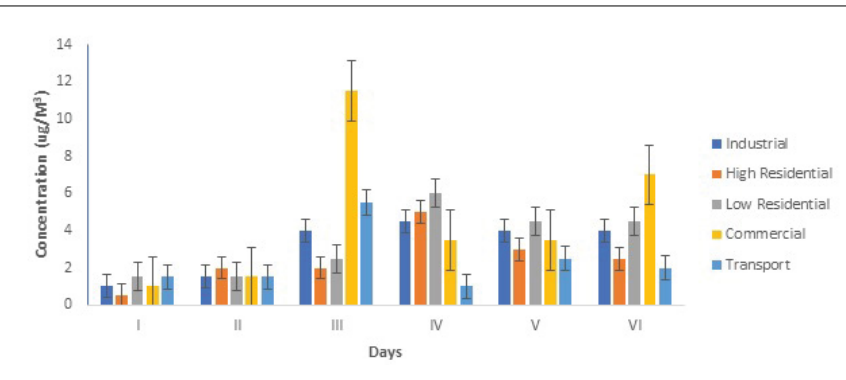

Figure 2: Mean Particulate Matter Concentration (PM1) in the Morning.

Table 1: Land use types, sample points, and coordinates.

\begin{tabular}{|c|c|c|c|c|c|c|c|}
\hline & $\mathrm{PM} 1$ & $\mathrm{PM} 2.5$ & $\mathrm{NO}_{2}$ & $\mathrm{CO}$ & Humidity & Temp. & Speed \\
\hline Industrial & $3.16 \pm$ & 11.75 & $0.08 \pm$ & $0.22 \pm$ & $81.44 \pm$ & $28.95 \pm$ & 1.59 \\
& $1.85^{\mathrm{a}}$ & $\pm 6.01^{\mathrm{ab}}$ & $0.013^{\mathrm{a}}$ & $0.28^{\mathrm{a}}$ & $3.59^{\mathrm{a}}$ & $1.37^{\mathrm{a}}$ & $\pm 0.52^{\mathrm{ab}}$ \\
\hline High density & $2.50 \pm$ & $11.91 \pm$ & 0.08 & $0.43 \pm$ & 80.66 & $29.10 \pm$ & 1.48 \\
Residential & $1.56^{\mathrm{a}}$ & $4.35^{\mathrm{ab}}$ & $\pm 0.008^{\mathrm{a}}$ & $0.72^{\mathrm{a}}$ & $\pm 4.55^{\mathrm{a}}$ & $1.64^{\mathrm{a}}$ & $\pm 0.48^{\mathrm{a}}$ \\
\hline Low density & 3.41 & 9.08 & $0.09 \pm$ & $0.39 \pm$ & 79.10 & 28.80 & 2.13 \\
Residential & $\pm 2.46^{\mathrm{a}}$ & $\pm 3.17^{\mathrm{a}}$ & $0.012^{\mathrm{a}}$ & $0.71^{\mathrm{a}}$ & $\pm 6.59^{\mathrm{a}}$ & $\pm 2.17^{\mathrm{a}}$ & $\pm 0.65^{\mathrm{bc}}$ \\
\hline Commercial & $4.66 \pm$ & 16.0 & $0.08 \pm$ & 0.48 & 81.54 & $29.35 \pm$ & $2.02 \pm$ \\
& $5.43^{\mathrm{a}}$ & $\pm 9.76^{\mathrm{b}}$ & $0.005^{\mathrm{a}}$ & $\pm 0.53^{\mathrm{a}}$ & $\pm 3.4^{\mathrm{a}}$ & $1.37^{\mathrm{a}}$ & $0.88^{\mathrm{ab}}$ \\
\hline \multirow{2}{*}{ Transport } & $2.33^{\mathrm{a}}$ & $10.0 \pm$ & $0.11 \pm$ & $7.06 \pm$ & 77.07 & $30.15 \pm$ & 2.62 \\
& $1.66^{\mathrm{a}}$ & $3.75^{\mathrm{a}}$ & $0.018^{\mathrm{b}}$ & $4.90^{\mathrm{b}}$ & $\pm 7.16^{\mathrm{a}}$ & $1.315^{\mathrm{a}}$ & $\pm 0.82^{\mathrm{c}}$ \\
\hline \multirow{2}{*}{ Total } & 3.21 & $11.76 \pm$ & 0.09 & 1.72 & $79.96 \pm$ & $29.47 \pm$ & $1.97 \pm$ \\
& \pm 2.99 & 6.18 & \pm 0.016 & \pm 3.46 & 5.38 & 0.759 & 0.78 \\
\hline
\end{tabular}

Table 2: The Means and Standard Deviation for Various Variables in the Morning for the Study Period; NB: Land use type with mean \pm std. for each variable with the same alphabet is not significant.

$\mathrm{NO}_{2}$ and $\mathrm{CO}$ but are significantly different from transport land use. Also, transport land use is significantly different from other land uses for wind speed.

In Table 3, the study revealed that PM 1 and PM 2.5 are the same for industrial, high residential, low residential and commercial land use types but are significantly different from transport land use. $\mathrm{NO}_{2}$ is significantly the same in all land use types but $\mathrm{CO}$ is significantly the same for industrial and low residential land uses as well as high residential and transport land use type but significantly different from commercial land use type. Also, humidity is the same for industrial, high residential and commercial land uses but significantly different from low residential and transport land use types. The table further shows that temperature in high residential land use area is significantly different from transport land use type but industrial and commercial land use is significantly the same. Consequently, wind speed is significantly different from commercial and transport land use but industrial, high and low residential land use is significantly the same (Figure 3). 
Citation: Weli VE, Adegoke J, Eyo BJ (2018) The Incidence of Soot and Surface Boundary Layer Meteorology in Port Harcourt Metropolis, Nigeria. J Climatol Weather Forecasting 6: 233. doi:10.4172/2332-2594.1000233

Page 4 of 9

The study further revealed that the sources of black carbon (soot) in the city are mainly from activities such as the operations of both legal (petrochemical industries) and illegal or artisanry refineries around the creek surround the city especially locations such as Rumuolumeli, Eagle Island, Woji creek etc; the activities of abattoirs at places like Slaughter, Ogunuabali, Rupukwu etc.

\section{Temporal variation of pollutants at different land-use types in Port Harcourt City}

\section{- Morning}

The One-way ANOVA in Table 4 above shows that there is no significant difference in the level of concentration of black carbon (PM 1 and PM 2.5) at the respective land use areas of Port Harcourt City, since p-values $(0.33$ and 0.06$)>0.05$ significant level respectively, thus the null hypothesis is accepted. However, the multiple comparison result using Least Significant Difference (LSD) shows that Commercial is significantly different from other land use but was same for Industrial, High Residential, Low Residential and Transport respectively (Figure 4).

\section{- Evening}

Table 3 shows that there is a significant difference in the level of concentration of black carbon (PM 1 and PM 2.5) at the respective land use areas of Port Harcourt City since p-values (0.00 and 0.00 respectively) $<0.05$ significant level. Thus the null hypothesis is rejected. However, the multiple comparison result using least significant difference (LSD) shows that Transport is significantly different from other land use but was same for Industrial, High Residential, Low Residential and Commercial respectively (Figure 5).

\section{- Morning}

Table 5 shows that there is a significant difference in the air pollutant parameters ( $\mathrm{NO} 2$ and $\mathrm{CO}$ ) across the different land use areas of Port Harcourt City, since p-values ( 0.00 and 0.00 respectively) $<0.05$ significant level, thus reject the null hypothesis (Figure 6). However, the multiple comparison result using Least Significant Difference (LSD) shows that Transport is significantly different from other land use but was same for Industrial, High Residential, Low Residential and commercial land use respectively. Also, $\mathrm{SO}_{2}$ was not significantly different in the different land use though it was observed to be negligible.

\section{- Evening}

Table 4 shows that there is a significant difference in the air pollutant parameter (CO) across the different land use areas of Port Harcourt City since p-values $(0.00)<0.05$ significant level (Figure 7). However, the multiple comparison result using Least Significant Difference (LSD) shows that High Residential and Transport land use is significantly different from other land use but was same for Industrial,

\begin{tabular}{|c|c|c|c|c|c|c|c|}
\hline & PM1 & PM2.5 & NO2 & CO & Humidity & Temp. & Speed \\
\hline Industrial & $1.33 \pm 0.49^{\mathrm{a}}$ & $7.16 \pm 1.26^{\mathrm{a}}$ & $0.08 \pm 0.006^{\mathrm{a}}$ & $0.11 \pm 0.17^{\mathrm{a}}$ & $78.61 \pm 4.31^{\mathrm{a}}$ & $29.23 \pm 0.62^{\mathrm{bc}}$ & $2.41 \pm 0.964^{\mathrm{ab}}$ \\
\hline High density Residential & $1.25 \pm 0.62^{\mathrm{a}}$ & $8.00 \pm 2.04^{\mathrm{a}}$ & $0.15 \pm 0.221^{\mathrm{a}}$ & $3.98 \pm 0.55^{\mathrm{b}}$ & $78.03 \pm 3.65^{\mathrm{a}}$ & $29.56 \pm 1.06^{\mathrm{c}}$ & $2.78 \pm 1.074^{\mathrm{ab}}$ \\
\hline Low density Residential & $1.41 \pm 0.51^{\mathrm{a}}$ & $6.33 \pm 1.07^{\mathrm{a}}$ & $0.08 \pm 0.019^{\mathrm{a}}$ & $0.61 \pm 0.62^{\mathrm{a}}$ & $82.21 \pm 3.96^{\mathrm{b}}$ & $28.76 \pm 0.67^{\mathrm{ab}}$ & $2.70 \pm 1.196^{\mathrm{ab}}$ \\
\hline Commercial & $2.25 \pm 1.65^{\mathrm{a}}$ & $8.66 \pm 2.34^{\mathrm{a}}$ & $0.09 \pm 0.007^{\mathrm{a}}$ & $2.57 \pm 1.60^{\mathrm{ab}}$ & $78.28 \pm 4.70^{\mathrm{a}}$ & $29.09 \pm 0.34^{\mathrm{bc}}$ & $3.07 \pm 1.02^{\mathrm{b}}$ \\
\hline Transport & $4.75 \pm 3.13^{\mathrm{b}}$ & $14.0 \pm 5.95^{\mathrm{b}}$ & $0.24 \pm 0.339^{\mathrm{a}}$ & $8.06 \pm 3.02^{\mathrm{c}}$ & $83.44 \pm 1.78^{\mathrm{b}}$ & $28.35 \pm 0.215^{\mathrm{a}}$ & $1.93 \pm 0.606^{\mathrm{a}}$ \\
\hline Total & $2.20 \pm 2.07$ & $8.83 \pm 4.04$ & $0.13 \pm 0.185$ & $3.07 \pm 4.02$ & $80.11 \pm 4.33$ & $29.00 \pm 0.759$ & $2.58 \pm 1.034$ \\
\hline
\end{tabular}

Table 3: The Means and Standard Deviation for Various Variables in the Evening for the Study Period;NB: Land use type with mean std. for each variable with the same alphabet is not significant.

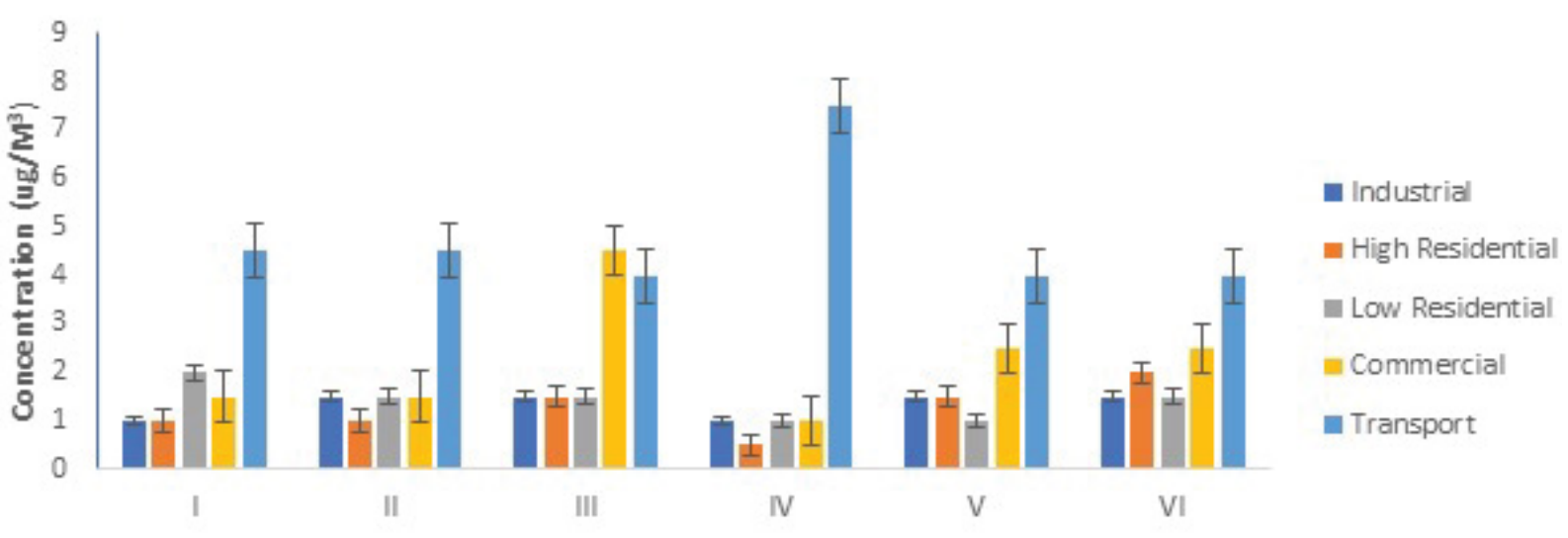

Days

Figure 3: Mean Particulate Matter Concentration (PM1) in the evening

\begin{tabular}{|c|c|c|c|c|c|}
\hline Time & Variable & Df & F-Statistic & P-value & Significant Level \\
\hline \multirow{2}{*}{ Morning } & PM 1 & 4 & 1.165 & 0.336 & 0.05 \\
\hline \multirow{2}{*}{ Evening } & PM 2.5 & 4 & 2.403 & 0.061 & Not Significant (Accept H01) \\
\cline { 2 - 6 } & PM 1 & 4 & 9.758 & 0 & Not Significant (Accept H01) \\
\hline
\end{tabular}

Table 4: ANOVA Results for Black Carbon. 


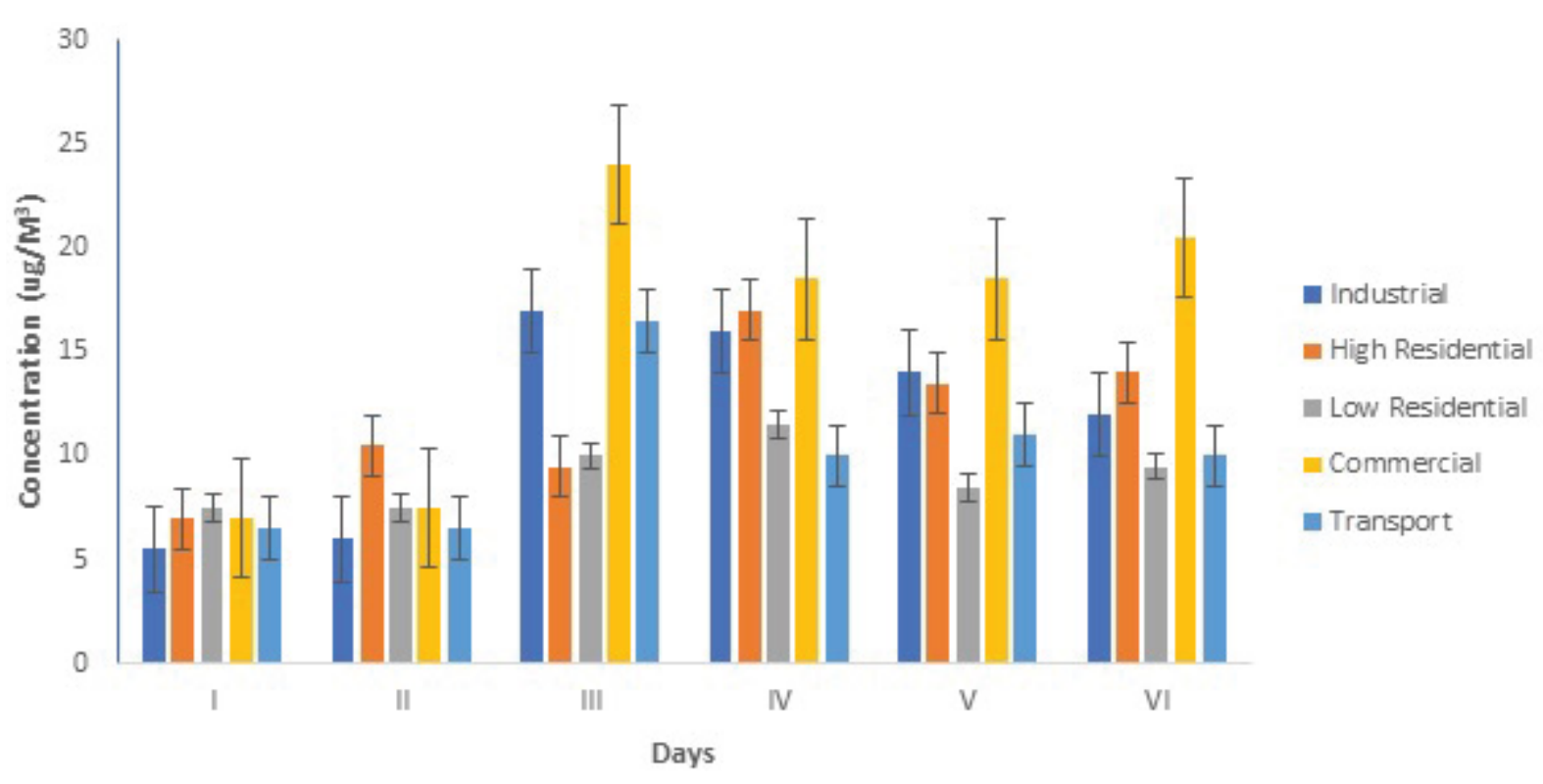

Figure 4: Mean Particulate Matter Concentration (PM2.5) in the Morning.

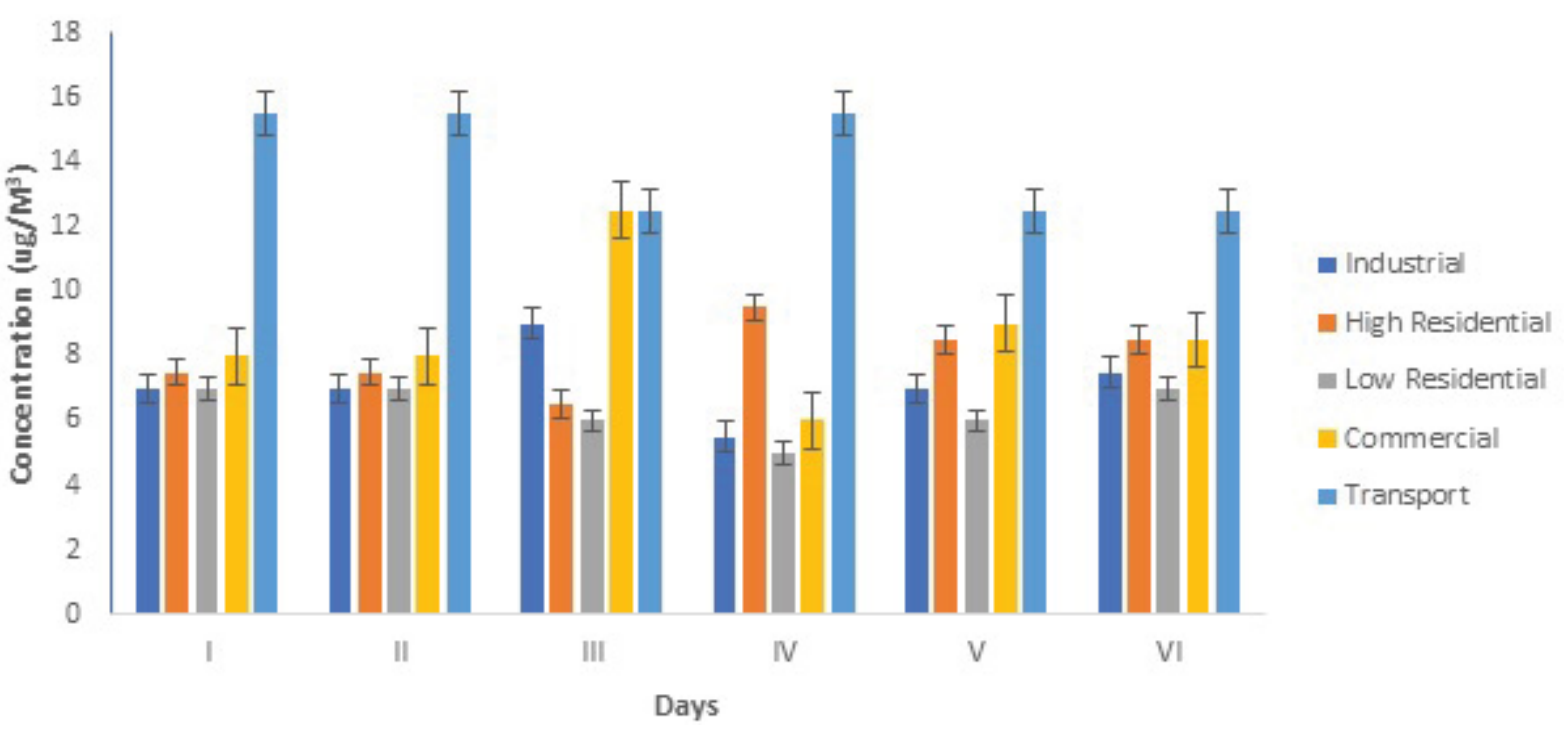

Figure 5: Mean Particulate Matter Concentration (PM2.5) in the Evening.

\begin{tabular}{|c|c|c|c|c|c|c|}
\hline Time & Variable & Df & F-Statistic & P-value & Significant Level & Decision \\
\hline \multirow{2}{*}{ Morning } & $\mathrm{NO}_{2}$ & 4 & 12.283 & 0 & 0.05 & Significant (Reject $\mathrm{HO}_{2}$ ) \\
\hline & $\mathrm{CO}$ & 4 & 21.102 & 0 & 0.05 & Significant (Reject $\mathrm{HO}_{2}$ ) \\
\hline \multirow{2}{*}{ Evening } & $\mathrm{NO}_{2}$ & 4 & 1.675 & 0.169 & 0.05 & Significant (Accept $\mathrm{HO}_{2}$ ) \\
\hline & $\mathrm{CO}$ & 4 & 14.406 & 0 & 0.05 & Significant (Reject $\mathrm{HO}_{2}$ ) \\
\hline
\end{tabular}

Table 5: ANOVA Results for Air Pollutant Parameters.

Low Residential, and commercial land use respectively. Consequently, the One-way ANOVA table as shown in Table 5 further indicated that there is no significant difference in the air pollutant parameter $\left(\mathrm{NO}_{2}\right)$ across the different land use areas of Port Harcourt City since p-values (0.169) $>0.05$ significant level (Figure 8). The multiple comparison result using Least Significant Difference (LSD) shows that the land use types are not significantly different. Also, $\mathrm{SO}_{2}$ was not significantly different in the different land use though it was observed to be negligible.

The relationship between surface boundary meteorology and black carbon concentration

The result of multiple regression conducted to examine whether 


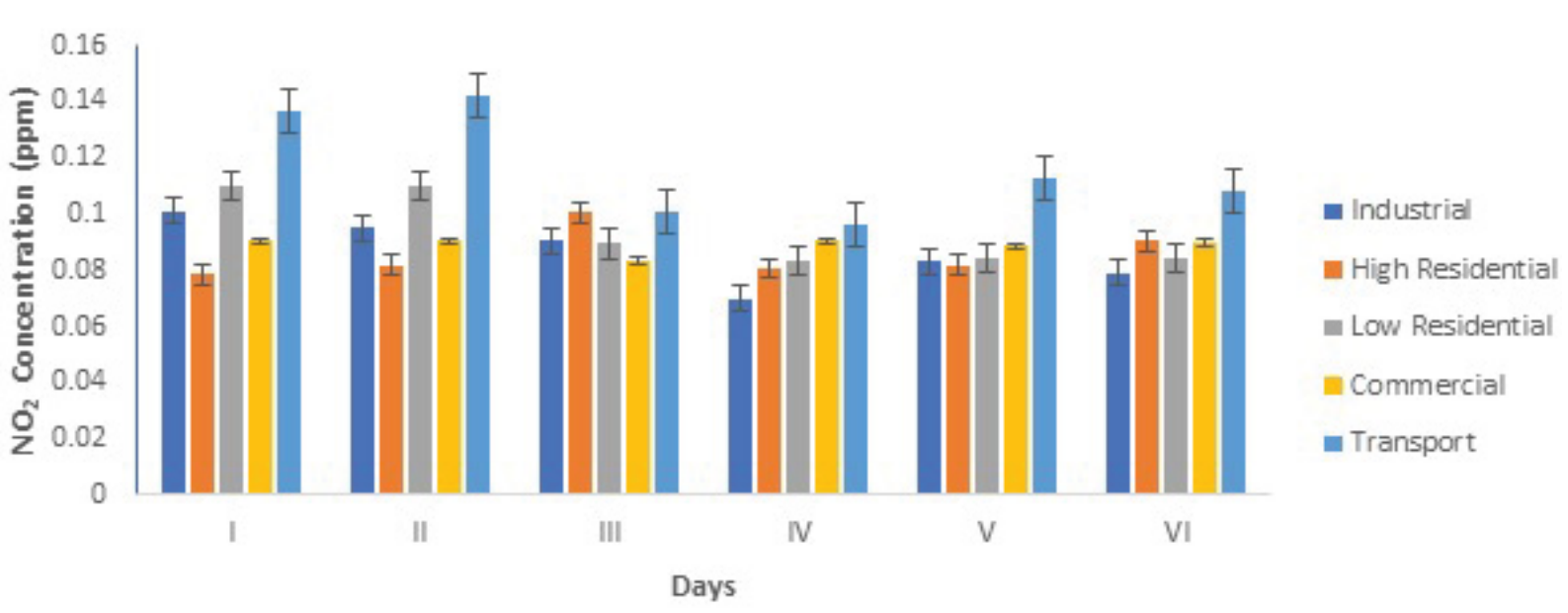

Figure 6: Mean Pollutant Concentration (NO2) in the Morning.

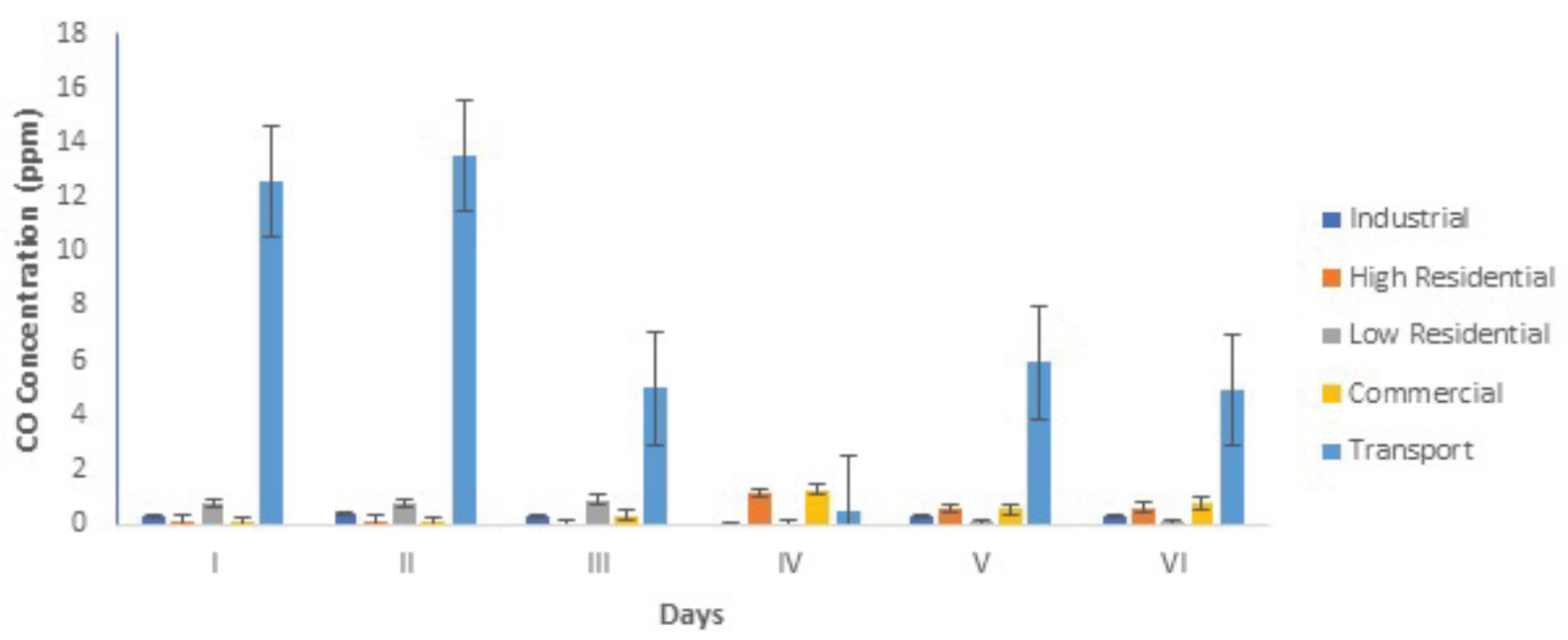

Figure 7: Mean Pollutant Concentration (CO) in the Morning.

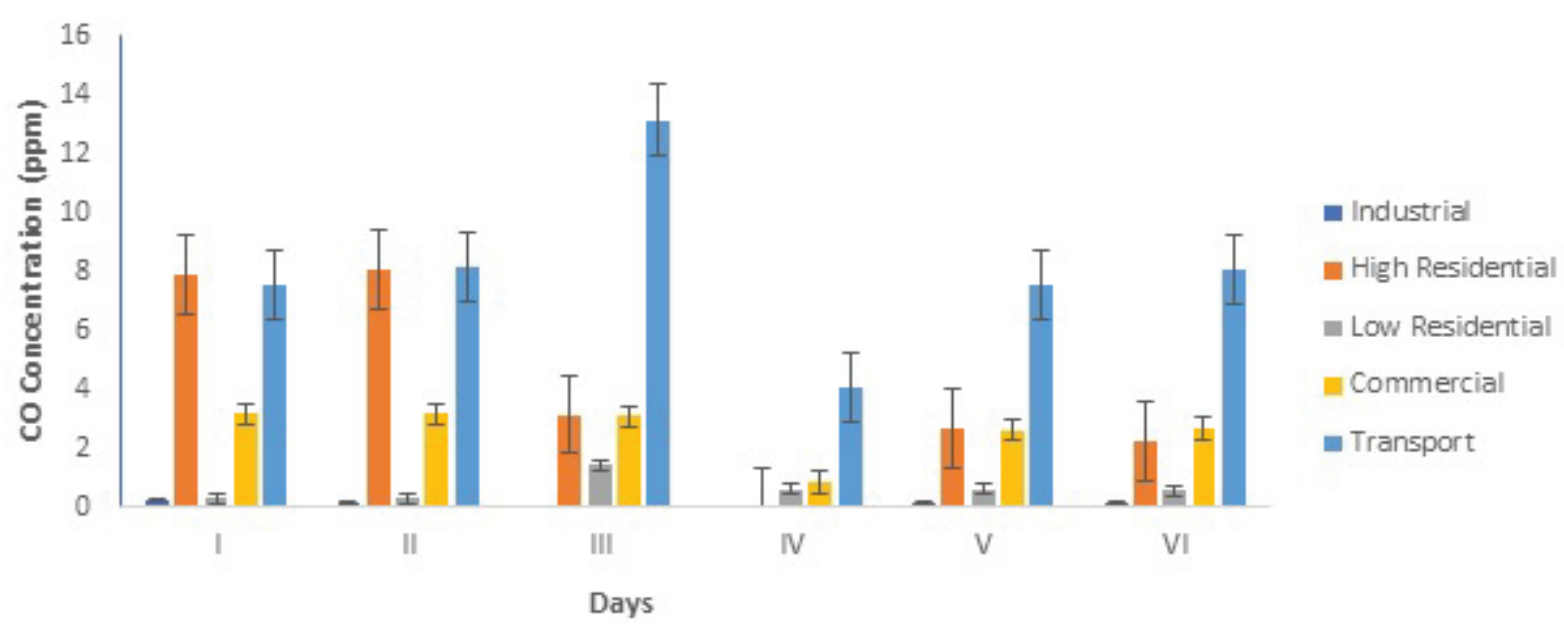

Figure 8: Mean Pollutant Concentration (NO2) in the Evening.

humidity, temperature and speed impact on the overall concentration of black carbon (Table 7). The R-square which is the proportion of variation in the dependent variable (CO) that is explained by the three independent meteorological variables (humidity, temperature, and 
Citation: Weli VE, Adegoke J, Eyo BJ (2018) The Incidence of Soot and Surface Boundary Layer Meteorology in Port Harcourt Metropolis, Nigeria. J Climatol Weather Forecasting 6: 233. doi:10.4172/2332-2594.1000233

Page 7 of 9

speed). The overall model explained $14 \%$ of variance in concentration of CO was revealed to be statistically significant, F $(3,56)=3.174$, p $(0.031)<5 \%$ (Table 6 ). An assessment of individual predictors revealed that humidity (Beta $=0.112, \mathrm{p}>5 \%)$, temperature (Beta $=0.185, \mathrm{p}>5 \%)$ and wind speed $($ Beta $=-1.419, \mathrm{p}<5 \%)$ are significant predictors of overall detection $\mathrm{CO}$

\section{Model 4.4:}

Carbon Monoxide $(\mathrm{CO})=\beta 0+\beta 1($ Humidity $)+\beta 2($ Temp. $)+$ $\beta 3($ Speed $)+\varepsilon$

\section{- Morning}

\section{Model 4.5:}

Black Carbon $($ PM1 $)=\beta 0+\beta 1$ (Humidity $)+\beta 2($ Temp. $)+\beta 3$ $($ Speed $)+\varepsilon$

The tables above (Tables 8-10) shows that the simple model is not adequate at $\mathrm{p}$-value $(0.11)>5 \%$ significant level, this explains there is no relationship between humidity, temperature, and speed. The adjusted $\mathrm{R} 2$ shows that only $5 \%$ of PM1 is affected by metrological parameters. Similarly, the simple model coefficients $(\beta 0=-39.33, \beta 1=0.3070$, $\beta 2=0.623$ and $\beta 3=-0.205)$ further explains the insignificant prediction of black carbon (soot) concentration. We thus conclude that there is no significant relationship between metrological parameters and black carbon (PM1) concentration.

\section{- Evening}

Model 4.6:

Black Carbon $($ PM1 $)=\beta 0+\beta 1$ (Humidity) $+\beta 2($ Temp. $)+\beta 3$ (Speed) $+\varepsilon$

The multiple regressions is conducted to examine whether humidity, temperature and speed impact on overall detection PM1 (Table 11) The R-square is the proportion of variation in the dependent variable (PM1) that is explained by the three independent variables (humidity, temperature and speed) (Figure 9). The overall model explained 13\% of variance in detection of PM1, which was revealed to be statistically significant, $\mathrm{F}(3,56)=2.907, \mathrm{p}(0.043)<5 \%$. An assessment of individual predictors revealed that humidity (Beta $=0.088, \mathrm{p}>5 \%$ ), temperature $($ Beta $=-0.383, \mathrm{p}>5 \%)$ and speed $($ Beta $=-1.118, \mathrm{p}>5 \%)$ are not significant predictors of overall detection of PM1.

\begin{tabular}{|c|c|c|c|c|c|c|c|c|c|c|}
\hline \multirow{2}{*}{ Model } & \multirow{2}{*}{$\mathbf{R}$} & \multirow{2}{*}{ R Square } & \multirow{2}{*}{ Adjusted R Square } & \multirow{2}{*}{ Std. Error of the Estimate } & \multicolumn{5}{|c|}{ Change Statistics } & \multirow{2}{*}{ Durbin-Watson } \\
\hline & & & & & R Square Change & F Change & df1 & df2 & Sig. F Change & \\
\hline 1 & $.381 a$ & 0.145 & 0.1 & 3.82224 & 0.145 & 3.174 & 3 & 56 & 0.031 & 1.746 \\
\hline
\end{tabular}

Table 6: Model Summary of the relationship between $\mathrm{CO}$ and surface boundary meteorology of Port Harcourt city; a. Predictors: (Constant), Speed, Temp, Humidity;b. Dependent Variable: CO

\begin{tabular}{|c|c|c|c|c|c|c|}
\hline \multicolumn{2}{|c|}{ Model } & \multicolumn{2}{|c|}{ Unstandardized Coefficients } & Standardized Coefficients & \multirow{2}{*}{ S } & Beta \\
\cline { 2 - 7 } & B & Std. Error & -1.011 & 0.317 \\
\hline \multirow{4}{*}{1} & (Constant) & -41.883 & 41.44 & 0.12 & 0.622 & 0.536 \\
\cline { 2 - 7 } & Humidity & 0.112 & 0.179 & 0.258 & 1.343 & 0.185 \\
\cline { 2 - 7 } & Temp & 1.368 & 1.019 & -0.364 & -2.857 & 0.006 \\
\hline
\end{tabular}

Table 7: Coefficientsa of the regression model of CO and meteorology in the evening period;a. Dependent Variable: COconcentration.

\begin{tabular}{|c|c|c|c|c|c|c|c|c|c|c|}
\hline \multirow{2}{*}{ Model } & \multirow{2}{*}{$\mathbf{R}$} & \multirow{2}{*}{ R Square } & \multirow{2}{*}{ Adjusted R Square } & \multirow{2}{*}{ Std. Error of the Estimate } & \multicolumn{5}{|c|}{ Change Statistics } & \multirow{2}{*}{ Durbin-Watson } \\
\hline & & & & & R Square Change & F Change & df1 & df2 & Sig. F Change & \\
\hline 1 & $.318 a$ & 0.101 & 0.053 & 2.9121 & 0.101 & 2.094 & 3 & 56 & 0.111 & 2.195 \\
\hline
\end{tabular}

Table 8: Model Summary of black soot (PM1) in the morning period;a Predictors: (Constant), SPEED m/s, TEMP.0C, HUMIDITY\% ;b Dependent Variable: PM1.

\begin{tabular}{|c|c|c|c|c|c|c|}
\hline & \multirow{2}{*}{ Model } & \multicolumn{2}{|c|}{ Unstandardized Coefficients } & \multirow{2}{*}{$\begin{array}{c}\text { Standardized Coefficients } \\
\text { Beta }\end{array}$} & \multirow{2}{*}{$\mathbf{t}$} & \multirow{2}{*}{ Sig. } \\
\hline & & B & Std. Error & & & \\
\hline \multirow{4}{*}{1} & (Constant) & -39.338 & 23.08 & & -1.704 & 0.094 \\
\hline & HUMIDITY\% & 0.307 & 0.135 & 0.553 & 2.272 & 0.027 \\
\hline & TEMP.OC & 0.623 & 0.449 & 0.337 & 1.387 & 0.171 \\
\hline & SPEED m/s & -0.205 & 0.485 & -0.054 & -0.423 & 0.674 \\
\hline
\end{tabular}

Table 9: Coefficients of the regression model for PM 1 and meteorological parameters in the morning period;a.Dependent Variable: PM1.

\begin{tabular}{|c|c|c|c|c|c|c|c|c|c|c|}
\hline \multirow{2}{*}{ Model } & \multirow{2}{*}{$\mathbf{R}$} & \multirow{2}{*}{ R Square } & \multirow{2}{*}{ Adjusted R Square } & \multirow{2}{*}{ Std. Error of the Estimate } & \multicolumn{5}{|c|}{ Change Statistics } & \multirow{2}{*}{ Durbin-Watson } \\
\hline & & & & & R Square Change & F Change & df1 & df2 & Sig. F Change & \\
\hline 1 & $.367 a$ & 0.135 & 0.088 & 1.97948 & 0.135 & 2.907 & 3 & 56 & 0.043 & 2.165 \\
\hline
\end{tabular}

Table 10: Model Summary of soot (PM1) in the morning period ;a. Predictors: (Constant), SPEED m/s, TEMP.0C, HUMIDITY\% ;b. Dependent Variable: PM1.

\begin{tabular}{|c|c|c|c|c|}
\hline \multirow{2}{*}{ Model } & Unstandardized Coefficients & & Standardized Coefficients & S \\
\cline { 2 - 5 } & B & Std. Error & Beta & 0.327 \\
\hline (Constant) & 7.01 & 21.461 & 0.183 & 0.945 \\
\hline HUMIDITY\% & 0.088 & 0.093 & -0.14 & -0.725 \\
\hline TEMP.0C & -0.383 & 0.528 & -0.143 & -1.118 \\
\hline SPEED m/s & -0.288 & 0.257 & 0.471 & \\
\hline
\end{tabular}

Table 11: Coefficients of the regression model for PM1 and meteorological parameters in the evening period.;a. Dependent Variable: PM1. 


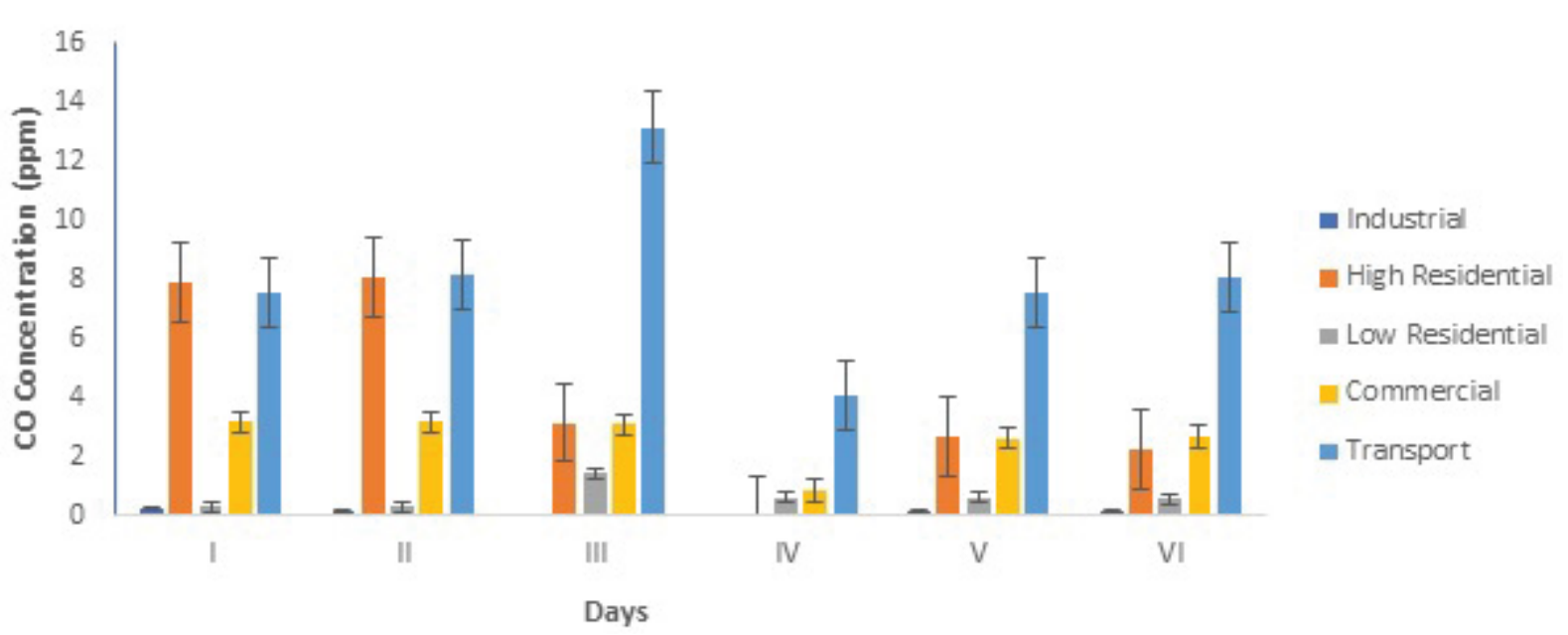

Figure 9: Mean Pollutant Concentration (CO) in the Evening.

\section{Conclusion}

This paper revealed that Black carbon concentration especially PM 1 and PM 2.5 which was very high at Commercial land use areas (Slaughter and Mile one), followed by the Low Residential land use areas (New GRA and Old GRA) for PM 1 and High Residential land use areas (Ogbunabali and Diobu) for PM 2.5 in the morning study period. While in the evening period, the black carbon concentration (PM1 and PM2.5) was also very high at the transport land use areas (Rumuola and Waterlines), closely followed by the commercial land use areas (Slaughter and Mile one). It was further revealed that for both morning and evening study period, there was no significant difference in concentration of black carbon in the respective land use areas of Port Harcourt City for PM1 but there was a significant difference in concentration of black carbon at respective land use areas of Port Harcourt City for PM 2.5. Also, there was a significant difference in air pollutant parameters across the different land use areas of Port Harcourt city at both morning and evening study periods. Similarly, there was a significant relationship between metrological parameters (humidity, Temperature and wind speed) and both pollutants concentration $\left(\mathrm{NO}_{2}\right.$ and $\left.\mathrm{CO}\right)$ during the morning study period and for $\mathrm{CO}$ during the evening study period. While there was no significant relationship for $\mathrm{NO}_{2}$ during the evening study period. By implication, the meteorological factors or parameters significantly influence pollutant concentration $\left(\mathrm{NO}_{2}\right.$ and $\left.\mathrm{CO}\right)$ or dispersion across the respective land use areas of Port Harcourt City except for NO2 at evening period. While $\mathrm{SO}_{2}$ was mostly observed to be below detectable limit (BDL) of the equipment used. On the contrary, there was no significant relationship between metrological parameters and black carbon (PM 1) concentration signifying they were not significant predictors to the overall detection of PM1 at both morning and evening study periods and PM 2.5 concentration at evening period. While there was a significant relationship between metrological parameters and Black carbon (PM 2.5) concentrates during the morning period.

\section{Recommendation}

From the above, the following recommendations are advised to help prevent epidemic outbreak and protection of the environment as well as improve the air quality;

There is a need for regular monitoring of atmospheric pollutants around the Port Harcourt region to forestall the potential health and atmospheric related impacts of such air toxics in the region.

There is urgent need to arrest the issue of illegal/artesianary refineries operations through granting of licenses to operators of such, which will enhance accountability, efficiency and effective monitoring/ control of their activities.

State of emergency should be declared on the incidence of air toxins in the atmosphere of the city.

Noise mask should be worn as a temporary and immediate measure to reduce exposure to the inhalation of PM1 and PM2.5

\section{Acknowledgements}

The authors acknowledge the Center for Disaster Risk and Development studies, University of Port Harcourt.

\section{Ethical Considerations}

The authors state that they have no ethical considerations.

\section{References}

1. Anenberg SC, Schwartz J, Shindell D, Amann M, Faluvegi G, et al. (2012) Global air quality and health co-benefits of mitigating near-term climate change through methane and black carbon emission controls. Environ Health Perspect 120: 831-839.

2. Haywood J M, Shine K P (1997) Multi-spectral Calculations of the Radiative Forcing of Tropospheric Sulphate and Soot Aerosols Using a Column Model, Q. J Roy Meteorol Soc 123: 1907-1930.

3. Myhre G, Stordal F, Restad K, Isaksen I S A.(1998)Estimation of the Direct Radiative Forcing Due to Sulfate and Soot Aerosols. Tellus 50: 463-477.

4. Jacobson M Z (2001) Strong radiative heating due to the mixing state of black carbon in atmospheric aerosols, Nature 409: 695-697.

5. Jacobson M Z (2001) Control of fossil-fuel particulate black carbon and organic matter, possibly the most effective method of slowing global warming, J Geophys Res Atmos 107: 4401.

6. Ozdemir H, Pozzoli L, Kindap T, Demir G,Mertoglu B, et al. (2014) Spatia and temporal analysis of black carbon aerosols in Istanbul megacity, Sci Total Environ 473: 451-458.

7. Graziosi F, Arduini J, Furlani F, Giostra U, Marinoni A, et al. (2015) Black Carbon and Agriculture - Source and Impacts; University of Urbino, Italy.

8. IPCC (Intergovernmental Panel on Climate Change) (2007) The Scientific Basis, in: Contribution of Working Group I to the Fourth Assessment Report of the Intergovernmental Panel on Climate Change, Cambridge Univ. Press, New York. 
Citation: Weli VE, Adegoke J, Eyo BJ (2018) The Incidence of Soot and Surface Boundary Layer Meteorology in Port Harcourt Metropolis, Nigeria. J Climatol Weather Forecasting 6: 233. doi:10.4172/2332-2594.1000233

Page 9 of 9

9. Udayasoorian C, Jayabalakrishnan R M, Suguna A. R, Mukunda M G, Suresh S.B. (2014) Aerosol black carbon characteristics over a high-altitude Western Ghats location in Southern India. Ann Geophys 32: 1361-1371

10. Jimenez J L, Canagaratna M R, Donahue N M, Prevot A S H, Zhang Q, et al. (2009) Evolution of organic aerosols in the atmosphere. Science 326: 1525-1529.

11. Schleicher N, Norra S, Fricker M, Kaminski U, Chen Y, et al. (2013) Spatiotemporal variations of black carbon concentrations in the Megacity Beijing. Environ Pollut 182: 392-401.

12. Bond T C, Doherty S J, Fahey D W, Forster P M, Berntsen T, et al. (2013) Bounding the role of black carbon in the climate system: A scientific assessment. J Geophys Res Atmos 118: 5380-5552.

13. Cao J J, Zhu C S, Chow J C,Watson J G, Han Y M, et al. (2009) Black Carbon Relationships with Emission and Meteorology in Xi'an, China. Atmos Res 94: 194-202.

14. Ramanathan V, Carmichael, G (2008) Global and regional climate changes due to black carbon, Nature Geoscience 221-222.

15. Dumka U C, Manchanda RK, Sinha P R, Sreenivasan S, Moorthy KK, et al. (2013) Temporal variability and radiative impact of black carbon aerosol over tropical urban station Hyderabad. J Atmos Sol Terr Phy 105: 81-90.

16. Robert B, Pope CA, Barry AF (2015) Air Pollution and Cardiovascular Disease, Current problems in cardiology 40: 207-238.

17. Weli, Ayoade (2014) Seasonal Analysis Of Atmospheric Pollutants
Concentrations In Urban And Rural Landuse Areas Of Rivers State, Nigeria. International Journal of Environment and Pollution Research 3: 48-61.

18. Zagha O, Nwaogazie I L (2015) Roadside Air Pollution Assessment in PortHarcourt, Nigeria, Standard Scientific Research and Essays. 3.

19. Ucheje O, Chiedozie I F (2015) Comparative analysis of vehicular emissions in urban and rural milieus: A case study of Port Harcourt and Etche in Rivers State, Nigeria, Arch Appl Sci Res 7: 39-44

20. Ede PN, Edokpa DO (2015) Regional Air Quality of the Nigeria's Niger Delta, Open Journal of Air Pollution 4: 17-15.

21. Weli VE, Adekunle $O$ (2014) Air quality in the vicinity of a Landfill site in Rumuolumeni, Port Harcourt, Nigeria. Journal of Environment and Earth Science 4: 1-9.

22. Weli VE (2014) Atmospheric Concentration of Particulate Pollutants and its Implications for Respiratory Health Hazard Management in Port Harcourt Metropolis, Nigeria. Civil and Environmental Research 6: 11-17.

23. Weli VE, Adegoke JO (2016) The influence of Meteorological Parameters and land use on the seasonal concentration of Carbon Dioxide (CO) in the industrial coastal city of Port Harcourt. J Pollut Eff Cont. 4: 1-8.

24. Ede PN, Edokpa D (2017) Satellite Determination of Particulate Load over Port Harcourt during Soot Incidents. Journal of Atmospheric Pollution 5: 55-61.

25. Weli VE, Emenike GC (2016) Turbulent weather events and air craft operations: Implications for Aviation Safety at the Port Harcourt International Airport,Nigeria. International Journal of Weather, Climate Change and Conservation Research 2: 11-21. 